\title{
Improvement of the Early Age Strength of Low Cement Concrete Using High Volume Mineral Admixture
}

\author{
Park, Jong $-\mathrm{Ho}^{1}$ Kim, Yong-Ro ${ }^{2}$ Song, Young-Chan ${ }^{2}$ Song, Dong Yub ${ }^{3}$ Kim, Gyu-Yong ${ }^{4 *}$ \\ Technology Research \& Development Institute, Sampyo, Gwangju-Si, Gyeonggi-Do, 464-080, Korea ${ }^{1}$ \\ Technology Research \& Development Institute, Daelim Industrial, Jongno-Gu, Seoul, 110-732, Korea ${ }^{2}$ \\ Korea Infrastructure Safety and Technology Corporation, Goyang-si, Gyeonggi-do, 411-807, Korea ${ }^{3}$ \\ Department of Architectural Engineering, Chungnam National University, Yuseong-Gu, Daejeon, 305-764, Korea ${ }^{4}$
}

\section{Abstract}

To address the problem of global warming, consumption of cement, the main material of concrete, should be decreased. Unfortunately, when industrial by-products are used in large quantities as admixture, the early age strength of concrete will be decreased, reducing its viability for use in concrete structures. Therefore, in this study, the application of an ionization accelerator and alkaline activator as addition agent of superplasticizer were investigated to secure a similar early age strength to that of normal concrete, thus increasing the viability of low cement concrete. Through the investigation, it was found that specimens that used a combination of Alkaline-activator (Na2Sio3) and ionization accelerator (Amine) had the highest early and long-age compressive strength. From this, we can determine an appropriate range of application of superplasticizer to improve early-age compressive strength of low cement concrete.

Keywords : mineral admixture, low cement concrete, early age strength, ionization accelerator, alkaline activator

\section{Introduction}

\subsection{Research background and objective}

As global warming became a global issue, industries in Korea made investments in facilities and technology development to reduce greenhouse gas.

The construction industry has made efforts to reduce carbon dioxide emissions. As cement is known to emit a lot of carbon dioxide, the industry has been working to reduce the mix volume of cement used in construction, utilizing fine powdery industrial byproducts including fly ash and blast furnace slag[1].

Received : May 7, 2012

Revision received : September 18, 2012

Accepted : October 8, 2012

* Corresponding author : Kim, Gyu-Yong

[Tel: +82-41-821-5623, E-mail: gyuyongkim@cnu.ac.kr]

(c)2012 The Korea Institute of Building Construction, All rights reserved.
However, when the admixture of industrial byproduct is replaced with more cement, the main component of concrete, early age strength is reported to be deteriorated, which becomes a drawback for its use as structural concrete[2,3].

For this reason, this study aims to derive a plan to secure an early age strength similar to that of conventional concrete in order to expand the viability of concrete in which the cement is replaced with admixture (hereinafter, "low cement concrete").

\subsection{Research method and scope}

To improve the early age strength of concrete, the unit volume of cement is increased, a material that can accelerate the hydration reaction is applied, and the curing temperature is raised. To minimize the mix volume of cement and improve the viability of low cement concrete, the use of a 
hydration accelerator is believed to be most effective[4,5,6].

Superplasticizer has been reported to accelerate hydration and reaction in cement. Therefore, the research scope was limited to the use of superplasticizer in a liquid form to improve the early age strength of the low cement concrete that is made using less volume of cement compared to conventional concrete.

\section{Review of reaction accelerators}

\subsection{Ionization accelerator}

If the elution of calcium ions $\left(\mathrm{Ca}^{2+}\right)$ and hydroxyl ions $\left(\mathrm{OH}^{-}\right)$from the minerals of cement, including $\mathrm{C}_{3} \mathrm{~S}, \mathrm{C}_{2} \mathrm{~S}, \mathrm{C}_{3} \mathrm{~A}$ and $\mathrm{C}_{4} \mathrm{AF}$, is accelerated, the time taken for $\mathrm{Ca}^{2+}$ to become supersaturated is shortened, and the initial hydration in cement is known to be accelerated due to the rapid diffusion of $\mathrm{Ca}^{2+}$ and $\mathrm{OH}^{-}$through the layer of hydration products even after the initial hydrates were generated, which helps accelerate the initial hydration in cement[7].

Figure 1 shows the behaviors of compounds that can be easily movable within the cement liquid and hydrates. The behaviors were expressed with the relationship between the molecular conductivity and the peak and initial time of hydration heat, which shows the effect of ionization accelerators. The hydration is found to have been accelerated compared to Plain, which is cement mortar with no accelerator. Table 1 indicates the types and characteristics of ionization accelerators.

Of the ionization accelerators, powdery accelerators were excluded due to their poor usability in construction sites, and ionization accelerators that were expected to bring about an increase in production cost when applied to low cement concrete compared to when applied to general cement concrete were also excluded; however, amine (TEA: $\left.\mathrm{C}_{18} \mathrm{H}_{41} \mathrm{NO}_{7} \mathrm{~S}\right)$, sulfate $\left(\mathrm{Na}_{2} \mathrm{SO}_{4}\right)$, nitrate $\left(\mathrm{Na}\left(\mathrm{NO}_{3}\right)_{3}\right)$ and $\mathrm{SCN}(\mathrm{NaSCN})$ were considered to be applicable without any increase in cost, and thus each were reviewed in terms of acceleration.

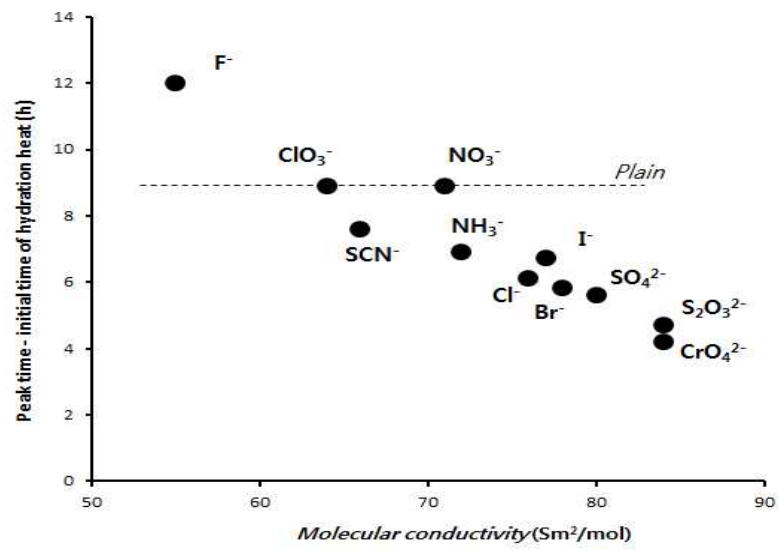

Figure 1. Acceleration effect of hydration with molecular conductivity

Table 1. Examples and characteristics of ionization accelerator

\begin{tabular}{|c|c|c|}
\hline Type & Compound & Characteristics \\
\hline Amine & TEA & $\begin{array}{l}\text { - High stability } \\
\text { - Advantage on the fluidity }\end{array}$ \\
\hline Thiocyanate & $\mathrm{NaSCN}$ & $\begin{array}{l}\text { - Excellent strength development } \\
\text { - Significant slump loss }\end{array}$ \\
\hline Chlorine & $\mathrm{CaCl}_{2}$ & $\begin{array}{l}\text { - Detection of chloride } \\
\text { - Excellent strength development }\end{array}$ \\
\hline Sulfate & $\mathrm{Na}_{2} \mathrm{SO}_{4}$ & $\begin{array}{l}\text { - Excellent early strength } \\
\text { - Decline of long-term strength }\end{array}$ \\
\hline Chromium & $\mathrm{Cr}_{3} \mathrm{Na}_{2} \mathrm{O}_{7}$ & $\begin{array}{l}\text { - Excellent strength development } \\
\text { - Significant slump loss }\end{array}$ \\
\hline Nitrate & $\mathrm{Na}\left(\mathrm{NO}_{3}\right)_{3}$ & $\begin{array}{l}\text { - Low strength development } \\
\text { - Advantage on the fluidity }\end{array}$ \\
\hline Bromine & $\mathrm{NaBr}$ & $\begin{array}{l}\text { - Excellent strength development } \\
\text { - Significant slump loss }\end{array}$ \\
\hline Fluoro & $\mathrm{CrF}_{2}$ & $\begin{array}{l}\text { - High reactivity } \\
\text { - Hazardous material }\end{array}$ \\
\hline
\end{tabular}

Table 2. Example and characteristic of alkaline activato

\begin{tabular}{ccl}
\hline Type & Compound & \multicolumn{1}{c}{ Characteristics } \\
\hline Silicate & $\mathrm{Na}_{2} \mathrm{SiO}_{3}$ & $\begin{array}{l}\text { - High reactivity } \\
\text { - Advantage on the long-term } \\
\text { strength }\end{array}$ \\
Hydroxide & $\mathrm{NaOH}$ & $\begin{array}{l}\text { - High reactivity } \\
\text { - Decline of fluidity }\end{array}$ \\
Carbonate & $\mathrm{Na}_{2} \mathrm{CO}_{3}$ & - Low reactivity \\
Sulfate & $\mathrm{CaSO}_{4}$ & - Low reactivity \& solubility \\
\hline
\end{tabular}




\subsection{Reaction accelerator}

As admixture, the fly ash or ground granulated blast furnace slag is not affected by hydration, but the $\mathrm{pH}$ level is raised by calcium hydroxide

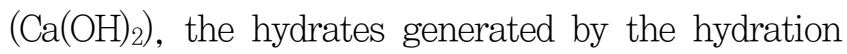
of cement, and this destroys the hyaline membrane and triggers a hydration reaction of blast furnace slag and a pozzolanic reaction that occurs between silica and alumina, the main components of the admixtures.

The material that accelerates the reaction of the admixture is referred to as an alkaline activator, and Table 2 indicates the representative types and characteristics of alkaline activators[8,9,10].

Through the advance review, silicate, hydroxide and carbonate were selected for evaluation in consideration of their usability as liquid type 1 super plasticizer.

\section{Experiment plan and method}

\subsection{Experiment plan}

The experiment plan of this research is shown in Table 3. The low cement concrete specimens within the range of normal compressive strength were tested to improve the early age strength. To examine the validity of ionization accelerators, four types of ionization accelerator were selected, each of which was set to add at five different ratios in the $1^{\text {st }}$ step, three types of alkaline activator were selected, and then the activators found to be valid were examined according to the addition rates in the $2^{\text {nd }}$ step.

Then, the strength development was examined by combining the accelerators and the activators found to be valid through the $1^{\text {st }}$ and $2^{\text {nd }}$ steps to derive the optimal combination ratio of accelerator and activator that helps develop early age strength in the $3^{\text {rd }}$ step.
The slump and air content of concrete were tested according to KS F 2402 and 2421. The tests were done in winter, the concrete was cured air dried state at $15^{\circ} \mathrm{C}$ for two days and then went through the standard curing process to conduct the tests of compressive strength in compliance with KS F 2405.

\subsection{Materials and mix proportion}

The physical properties of the materials and the chemical composition of binders used in this study are shown in Tables 4 and 5, respectively. For Plain $0.5 \%$ of naphthalene type superplasticizer was used, and for low cement concrete $1.3 \%$ of polycarbonylate type superplasticizer was used. The tests were then conducted by adding the accelerators and the activators as planned.

Table 6 indicates the mix proportion of concrete used in this study. For Plain the standard design strength was set at $24 \mathrm{MPa}$, which is the strength generally applied in construction sites, and $330 \mathrm{~kg} / \mathrm{m}^{3}$ unit binder weight, $140 \mathrm{~kg} / \mathrm{m}^{3}$ water content per unit volume of concrete, and $80 \%$ admixture replacement rate were used to mix low cement concrete, and this was found to secure the specified concrete strength at $24 \mathrm{MPa}$ at 28 days in the advance review.

Table 3. Experiment design

\begin{tabular}{|c|c|c|}
\hline Step & Factors & Levels \\
\hline 1 & $\begin{array}{l}\text { Ionization } \\
\text { accelerator }\end{array}$ & $\begin{array}{l}\text { - Amine, Sulfate, Nitrate, SCN } \\
\text { - Addition ratio : } 0 \sim 10 \%\end{array}$ \\
\hline 2 & $\begin{array}{l}\text { Alkaline } \\
\text { activator }\end{array}$ & $\begin{array}{l}\text { - } \mathrm{Na}_{2} \mathrm{SiO}_{3}, \mathrm{NaOH}, \mathrm{Na}_{2} \mathrm{CO}_{3} \\
\text { - Addition ratio : } 0 \sim 7 \%\end{array}$ \\
\hline 3 & $\begin{array}{l}\text { Use in } \\
\text { combination }\end{array}$ & $\begin{array}{l}\text { - Ionization accelerator+Alkaline activator } \\
\text { - combination ratio : } 1: 1 \text { or } 1: 1: 1 \\
\text { - Addition ratio }: 5 \%\end{array}$ \\
\hline \multicolumn{2}{|c|}{ Test items } & $\begin{array}{l}\text { - Slump \& Air contents (initial, 60min.) } \\
\text { - Compressive strength }(3,7,28 d)\end{array}$ \\
\hline
\end{tabular}


Table 4. Physical properties of material used

\begin{tabular}{|c|c|}
\hline Materials & Properties \\
\hline Cement & $\begin{array}{l}\text { - Ordinary Portland Cement (Type I ) } \\
\text { - Density } 3.15 \mathrm{~g} / \mathrm{cm}^{3} \text {, Blain 3,466 } \mathrm{cm}^{2} / \mathrm{g}\end{array}$ \\
\hline \multirow{2}{*}{$\begin{array}{l}\text { Mineral } \\
\text { admixture }\end{array}$} & $\begin{array}{l}\text { - Fly-Ash (Type } 2) \\
\text { - Density } 2.23 \mathrm{~g} / \mathrm{cm}^{3} \text {, Blain } 3,720 \mathrm{~cm}^{2} / \mathrm{g}\end{array}$ \\
\hline & $\begin{array}{l}\text { - Blast Furnace Slag (Type } 3 \text { ) } \\
\text { - Density } 2.91 \mathrm{~g} / \mathrm{cm}^{3} \text {, Blain } 4,497 \mathrm{~cm}^{2} / \mathrm{g}\end{array}$ \\
\hline Sand & $\begin{array}{l}\text { - Sea sand (Type 3) } \\
\text { - Density } 2.60 \mathrm{~g} / \mathrm{cm}^{3} \text {, FM } 2.77\end{array}$ \\
\hline Gravel & $\begin{array}{l}\text { - } 25 \mathrm{~mm} \text { Crushed Stone } \\
\text { - Density } 2.62 \mathrm{~g} / \mathrm{cm}^{3}, \text { FM } 7.05\end{array}$ \\
\hline Super plasticizer & $\begin{array}{l}\text { - Naphthalene Water reducing agent } \\
\text { - Polycarboxylate Water reducing agent }\end{array}$ \\
\hline
\end{tabular}

Table 5. Chemical composition of binder

\begin{tabular}{ccccccccc}
\hline & $\begin{array}{c}\mathrm{CaO} \\
(\%)\end{array}$ & $\begin{array}{c}\mathrm{SiO}_{2} \\
(\%)\end{array}$ & $\begin{array}{c}\mathrm{Al}_{2} \mathrm{O}_{3} \\
(\%)\end{array}$ & $\begin{array}{c}\mathrm{Fe}_{2} \mathrm{O}_{3} \\
(\%)\end{array}$ & $\begin{array}{c}\mathrm{MgO} \\
(\%)\end{array}$ & $\begin{array}{c}\mathrm{K}_{2} \mathrm{O} \\
(\%)\end{array}$ & $\begin{array}{c}\mathrm{Na}_{2} \mathrm{O} \\
(\%)\end{array}$ & $\begin{array}{c}\mathrm{SO}_{3} \\
(\%)\end{array}$ \\
\hline OPC & 60.2 & 21.6 & 5.1 & 3.3 & 2.3 & 1.0 & 0.5 & 1.5 \\
FA & 7.36 & 54.6 & 20.4 & 7.3 & 2.2 & 1.5 & 2.0 & 1.48 \\
BFS & 44.9 & 35.4 & 13.0 & 0.5 & 5.0 & 0.4 & - & 1.31 \\
\hline
\end{tabular}

Table 6. Mix proportion of concrete

\begin{tabular}{|c|c|c|c|c|c|c|c|c|}
\hline & \multirow{2}{*}{$\begin{array}{l}\text { W/B } \\
(\%)\end{array}$} & \multirow{2}{*}{$\begin{array}{l}\text { S/a } \\
(\%)\end{array}$} & \multicolumn{6}{|c|}{ Unit weight $\left(\mathrm{kg} / \mathrm{m}^{3}\right)$} \\
\hline & & & W & OPC & $\mathrm{FA}$ & BFS & S & $G$ \\
\hline Plain & 53.0 & 49.0 & 175 & 230 & 50 & 50 & 869 & 912 \\
\hline $\operatorname{LCC}^{*}$ & 42.4 & 46.5 & 140 & 66 & 132 & 132 & 852 & 987 \\
\hline
\end{tabular}

* Low Cement Concrete

Table 7. Slump with ionization accelerator

\begin{tabular}{ccccccccc}
\hline $\begin{array}{c}\text { Add. } \\
\text { ratio } \\
(\%)\end{array}$ & \multicolumn{2}{c}{ Amine } & \multicolumn{2}{c}{ Sulfate } & \multicolumn{2}{c}{ Nitrate } & \multicolumn{2}{c}{ SCN } \\
\cline { 2 - 8 } & init. & $60 \mathrm{~m}$. & init. & $60 \mathrm{~m}$. & init. & $60 \mathrm{~m}$. & init. & $60 \mathrm{~m}$. \\
\hline 0 & 230 & 215 & 220 & 210 & 220 & 210 & 220 & 210 \\
1 & 230 & 205 & 230 & 205 & 225 & 205 & 220 & 205 \\
3 & 235 & 220 & 220 & 190 & 230 & 205 & 225 & 205 \\
5 & 232 & 215 & 220 & 185 & 220 & 210 & 230 & 210 \\
7 & 230 & 210 & 225 & 185 & 220 & 205 & 220 & 205 \\
10 & 225 & 215 & 230 & 160 & 230 & 180 & 230 & 180 \\
\hline
\end{tabular}

\section{Examination and analysis of experiment results}

\subsection{Changes in physical properties by ionization accelerator}

Table 7 shows the changes in slump(flow삭제) by kind and addition ratio of ionization accelerator, and Figure 2 shows the slump loss ratio of low cement concrete by ionization accelerator at 60 minutes after mixing the concrete. Amine-type accelerator is shown to have been within $10 \%$ of slump loss ratio regardless of the addition rate in the scope of this research, which means that slump flow was secured. However, sulfate-type accelerator is shown to have exceeded $10 \%$ of the slump loss ratio even at an addition rate of $1 \%$, and as the rate of addition became higher, the slump loss rose accordingly. Nitrate-type accelerator and SCN accelerator are also shown to have had rapid slump loss once the rate of addition passed $7 \%$.

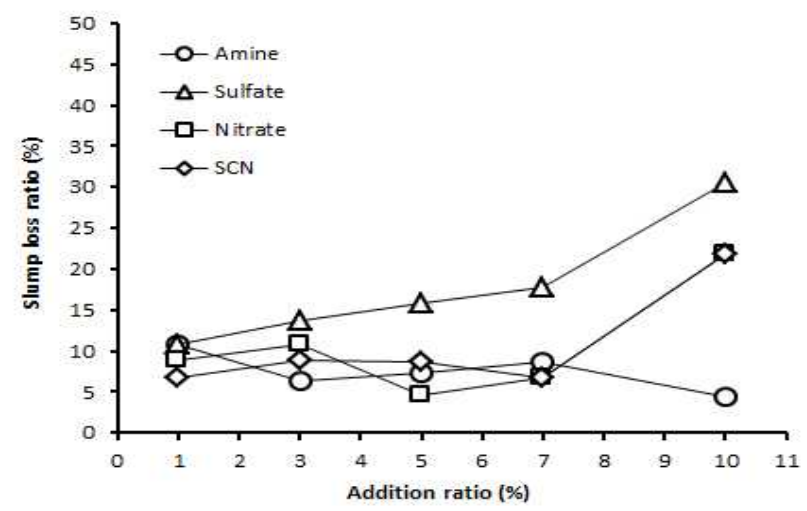

Figure 2. Slump loss ratio of low cement concrete using ionization accelerator

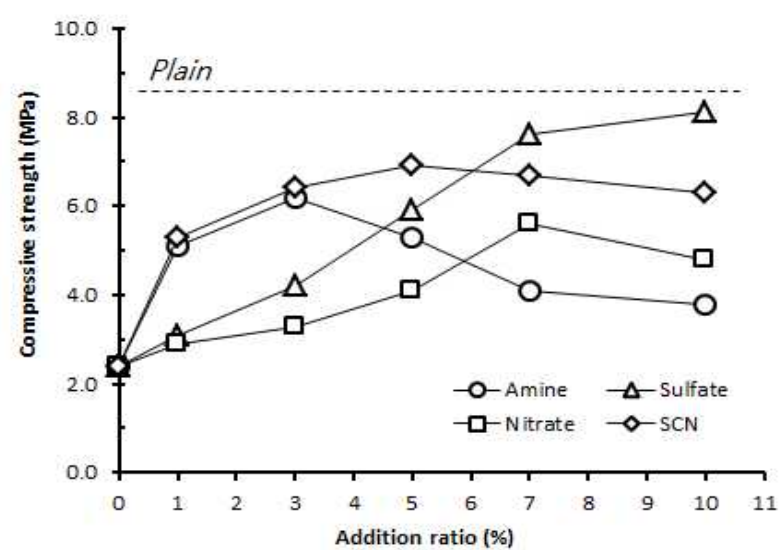

Figure 3. Compressive strength at 3 days of low cement concrete using ionization accelerator 


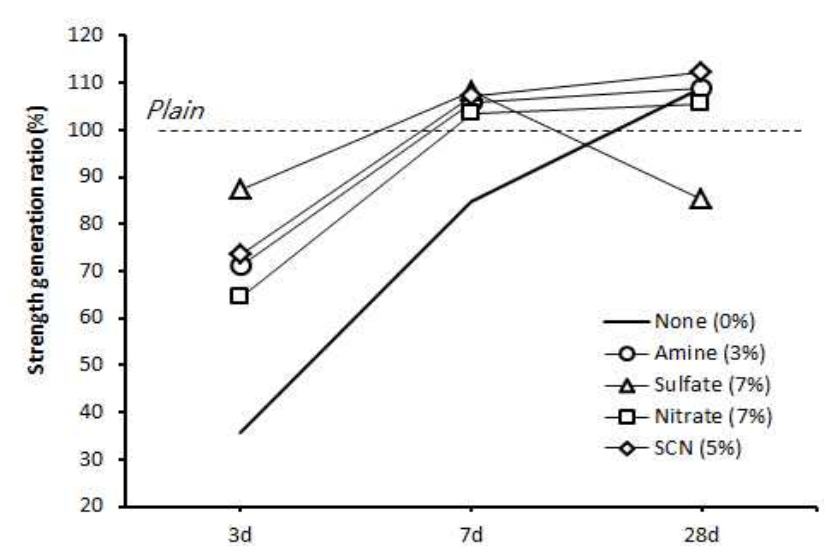

Figure 4. Strength generation ratio of low cement concrete using ionization accelerator

For this reason it is believed that when the concrete shows relatively higher slump loss, retardant should be increased in the delay component of superplasticizer to keep the slump flow at a certain level, which has an adverse influence on the development of early age strength. Based on this fact, the use of ionization accelerators other than amine-type should be restricted.

Figure 3 illustrates changes in compressive strength of low cement concrete at 3 days by ionization accelerator type and addition rate. All the accelerators had an effect on improving the early age strength; however, there were differences in strength by accelerator according to the addition rate. For amine-type and SCN, the early age strength was improved at a small addition rate, and then reduced once it went beyond a certain addition rate. For sulfate-type, there was no prominent effect when added at a small addition rate, but as the addition rate was higher, the early age strength was improved accordingly. And in case of Nitrate-type, improvement of early strength is lower than other type.

Through the analysis, the optimal addition rate for each accelerator was derived to improve the early age strength, and Figure 4 shows strength generation ratio of low cement concrete over Plain by age.

When the ionization accelerators were added, the early age strength was improved, but 65\% and 85\% of the strength was developed at 3 days compared to Plain. Based on the result, there seems to be a limit to the capacity to secure low cement concrete strength that is equivalent to or higher than that of Plain using only an ionization accelerator. However, the strength equivalent to or higher than that of Plain was developed after 7 days, and the low cement concrete with no accelerator is found to have developed the strength equivalent to or higher than Plain at 28 days.

Table 8 . Test result by mixed-use of ionization accelerator

\begin{tabular}{ccccccccc}
\hline \multirow{2}{*}{ Mix. } & $\begin{array}{c}\text { Air } \\
\text { Temp. }\end{array}$ & \multicolumn{2}{c}{$\begin{array}{c}\text { Slump } \\
(\mathrm{mm})\end{array}$} & \multicolumn{3}{c}{$\begin{array}{c}\text { Air content } \\
(\%)\end{array}$} & \multicolumn{4}{c}{$\begin{array}{c}\text { Compressive } \\
\text { Strength } \\
(\mathrm{MPa})\end{array}$} \\
\cline { 3 - 10 } & & init. & $60 \mathrm{~m}$. & init. & $60 \mathrm{~m}$. & $3 \mathrm{~d}$ & $7 \mathrm{~d}$ & $28 \mathrm{~d}$ \\
\hline Plain & 20.1 & 200 & 190 & 5.4 & 5.1 & 8.7 & 17.1 & 29.8 \\
None & 20.4 & 225 & 220 & 5.2 & 4.8 & 4.3 & 14.4 & 31.8 \\
A+SCN & 20.5 & 220 & 215 & 5.6 & 4.9 & 6.9 & 18.3 & 32.8 \\
A+S & 20.3 & 225 & 205 & 5.3 & 4.7 & 6.3 & 17.4 & 33.2 \\
A+S+SCN & 20.9 & 220 & 210 & 5.5 & 4.5 & 6.7 & 17.3 & 33.4 \\
\hline * A : Amine, & S : Sulfate & & & & & &
\end{tabular}

On the other hand, when using sulfate-type, which is found to have the best effect on improving the early age strength, the strength of low cement concrete stood at 85\% compared to that of Plain at 28 days, showing a reduction in long-term strength. It is believed that there is a limit to the extent to which raising the addition rate will improve the strength of low cement concrete when using sulfate-type as accelerator.

Based on the analysis results provided above, amine, sulfate and SCN are deemed to have an effect on improving the early age strength, and to evaluate the applicability of the combined use of 
accelerators to complement the characteristics of amine, sulfate and SCN, such as fluidity, strength development and mix ratio, the effect of the combined use was evaluated (addition rate was fixed at $5 \%$ when using the agents in combination), and the results are indicated in Table 8. When the addition rate was fixed at 5\%, the concrete was found to have slump loss that was not so high with the passage of time, and that there was nothing particular to secure air content.

Figure 5 shows strength development according to single and combined use of ionization accelerator by age. When using amine and SCN in combination, early age strength was slightly improved, but the differences were not great. As a result, there was no prominent effect on improving the early age strength with the use of accelerators in combination.

Through the analysis of the combined use of ionization accelerators, in terms of physical properties of fresh concrete and stable strength development, the combined use of amine and SCN ionization accelerators is found to have been effective.

\subsection{Changes in physical properties by alkaline activator}

To improve early age strength through reaction acceleration of admixture such as fly ash and blast furnace slag applied as admixture to low cement concrete, alkaline activator was added in superplasticizer and the changes in the physical properties of low cement concrete were examined.

Figure 6 illustrates changes in slump by alkaline activator. As is shown, all the alkaline activators selected in this study secured the required slump at early age, but the slump loss was shown to be higher than $27 \%$ over time compared to immediately after cement was mixed.
Figure 7 shows strength generation ratio of alkaline activator over Plain by age. From the results it is found that with the exception of $\mathrm{Na}_{2} \mathrm{CO}_{3}$, all the alkaline activators had an effect on improving the early age strength. The silicate alkaline activator, $\mathrm{Na}_{2} \mathrm{SiO}_{3}$, is shown to have had $94 \%$ of the early age strength of Plain, which was most effective in early age strength at 3 days.

When using $\mathrm{Na}_{2} \mathrm{CO}_{3}$, the superplasticizer was used relatively more than other activators to secure the initial slump. Later, the concrete was occur rapid setting phenomenon with slump loss, and strength development was retarded accordingly. The early age strength was examined in the concrete with different rates of addition of the alkaline activator, $\mathrm{Na}_{2} \mathrm{SiO}_{3}$, found to be effective in improving early age strength, and Figure 8 shows the results. It is found in the study that the higher the addition rate, the greater the early age strength. At the addition rate of 5\%, the early age strength was found to develop similarly to that of Plain.

However, in the evaluation by alkaline activator, at the addition rate of $3 \%$ the slump loss was found to be great. If an agent is used to retard slump loss, it is expected to decelerate early age strength development. Early age strength is developed only when the physical properties of fresh concrete satisfy certain conditions. The mix proportion of alkaline activator is believed to be limited.

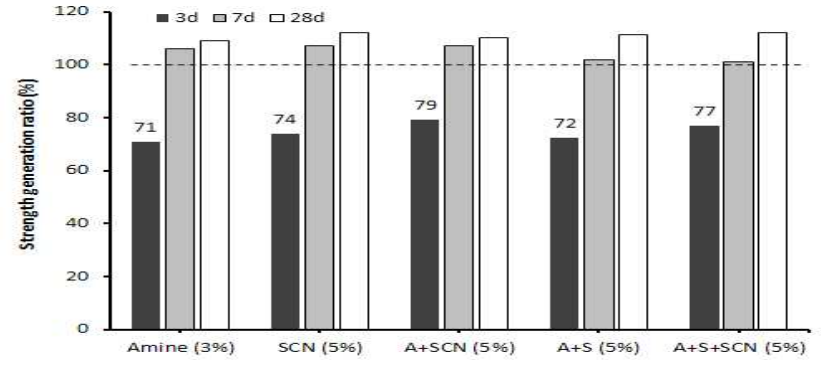

Figure 5. Strength generation ratio of low cement concrete according to using method of ionization accelerator 


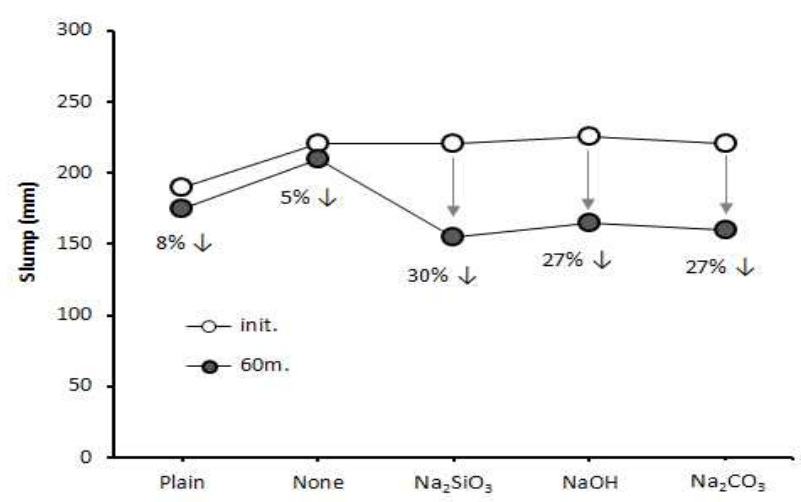

Figure 6. Slump with type of alkaline activator

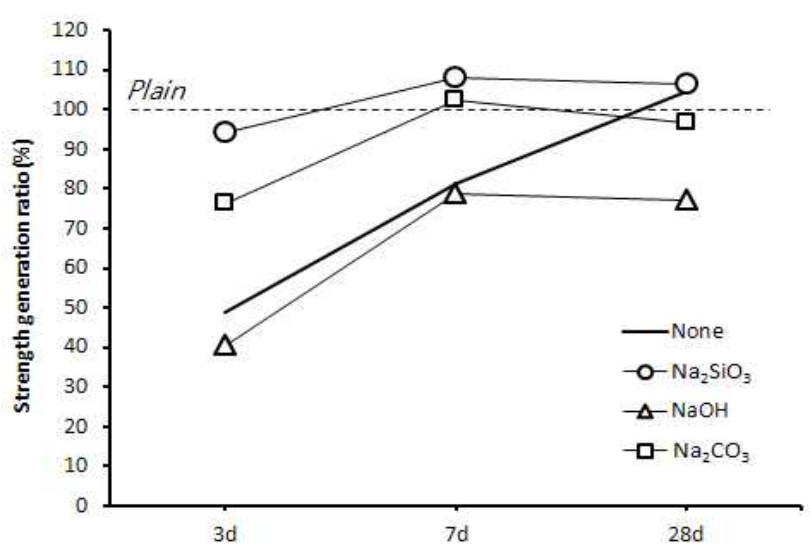

Figure 7. Strength generation ratio of low cement concrete using alkaline activator

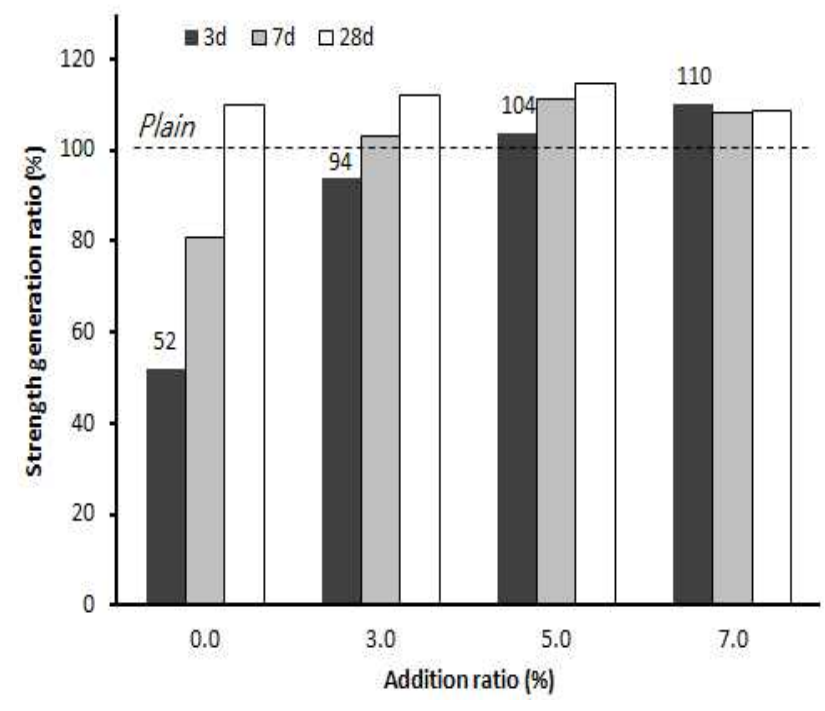

Figure 8. Strength generation ratio of low cement concrete according to addition ratio of $\mathrm{Na} 2 \mathrm{SiO} 3$

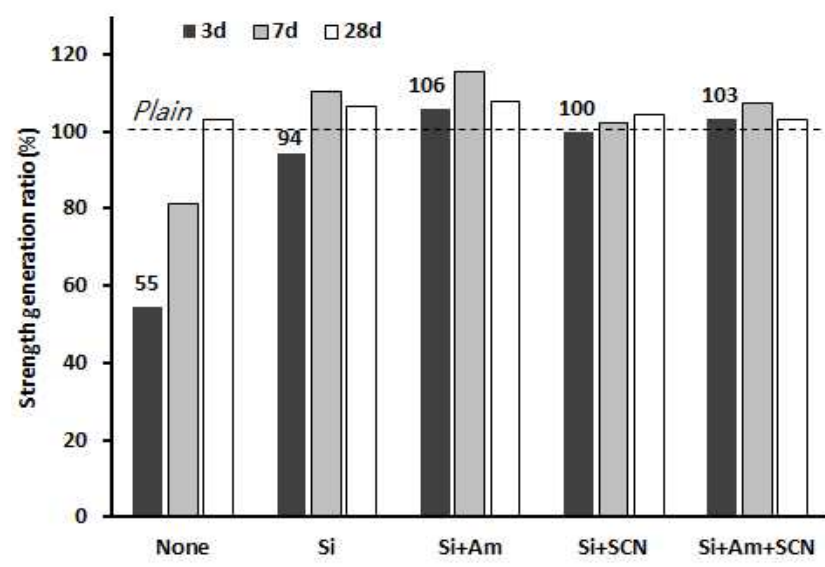

Figure 9. Strength generation ratio by mixed-use of alkaline activator and ionization accelerator
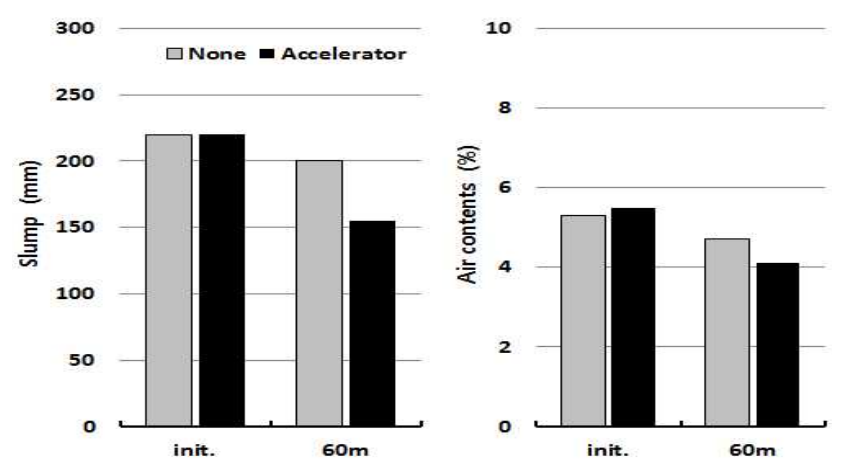

Figure 10. Slump and air content by use of accelerator

\subsection{Changes in physical properties by use of ionization accelerator and alkaline activator in combination}

As mentioned earlier, when an alkaline activator was used, the early age strength was improved, but the slump loss was also great, and its mix proportion would be limited. As an alternative, the use of accelerator and activator in combination was examined in this study.

For the combined use, amine and SCN were selected for accelerator and silicate for activator, as they were evaluated to be effective in terms of improving the strength.

Figure 9 illustrates changes in compressive strength generation ratio according to the combined use of agents. It was revealed that through the use of alkaline activator and 
accelerator in combination, the early age strength was shown to increase by $10 \%$ more than through the single use of an alkaline activator, and 30\% more than through the single use of an ionization accelerator.

In addition, in terms of early age strength and long-term strength, the use of " $\mathrm{Na}_{2} \mathrm{SiO}_{3}+$ amine" in combination was shown to be effective. On the other hand, Figure 10 shows the slump flow and air content of fresh concrete according to the use of " $\mathrm{Na}_{2} \mathrm{SiO}_{3}+$ amine" in combination. The slump was not improved compared to the single use of an alkaline activator, while slump loss was greater due to the addition of an accelerator. In terms of air content, there was no problem with securing the air content required by KS F 4009 under the condition; however, the slump flow should be maintained within the extent to which the early age strength was not retarded. Gluconic acid-based retardant was applied to maintain the slump.

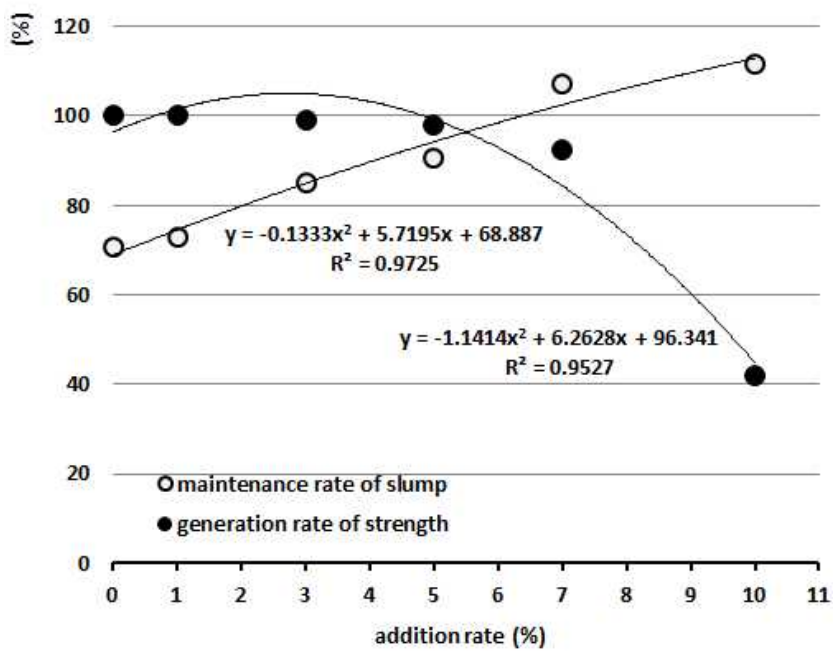

Figure 11. Maintenance rate of slump and generation rate of strength with addition rate of retardant

Figure 11 shows changes in slump and early age strength based on the addition of gluconic acid-based retardant at 3 days compared to immediately after the low cement concrete was mixed. From the figure, it is determined that the higher the addition rate, the more the early age strength was retarded; however, with an addition rate of up to $5 \%$, the early age strength was similar.

In addition, in terms of slump, the higher the addition rate of retardant, the longer the slump was maintained. However, when the generation rate of early age strength is considered with the slump, no more than 5\% gluconic acid-based retardant should be added. The applicability of reaction accelerator was examined by adding liquid superplasticizer to improve the early age strength of low cement concrete, and the combined use of accelerator with activator and the application of retardant were also examined to maintain the fluidity of the cement.

\section{Conclusion}

The purpose of this research is to present a plan for improving the early age strength of low cement concrete in which cement content is relatively less than existing conventional concrete. The material that can accelerate hydration in cement and reaction of admixture was added in the form of liquid super plasticizer, and the findings of this research are as follows:

1) From the results of the analysis of the use of ionization accelerators that accelerate hydration reaction in cement, amine and SCN accelerators are found to have been effective in terms of securing the physical properties of fresh low cement concrete and stable strength development.

2) When two ionization accelerators known to have an effect on improving early age 
strength were used in combination, the strength was slightly improved.

3) An analysis of the use of alkaline activators showed that the silicate activator, $\mathrm{Na}_{2} \mathrm{SiO}_{3}$, had the greatest effect on improving the early age strength; however, it is verified that when an alkaline activator was used, some measures should be taken to maintain the slump.

4) When the accelerator and activator were used in combination, the early age strength was improved by $10 \%$ compared to the single use of an alkaline activator, while it was improved by $30 \%$ compared to the single use of an accelerator. In terms of early and long-term strength, the combined use of " $\mathrm{Na}_{2} \mathrm{SiO}_{3}+$ amine" was shown to be effective.

5) The applicability of retardant was examined to maintain the slump flow when the alkaline activator and ionization accelerator were used together, and the extent to which the superplasticizer was applicable was determined in order to improve the early age strength of low cement concrete.

\section{References}

1. Lee HS. $\mathrm{CO}_{2}$ Reduction technology for concrete. Magazine of the Korea Concrete Institute. 2011 November;23(6):28-31.

2. Han CG, Park YK. Effect of performance materials on the affecting early-age strength of concrete replacement fly ash. Journal of the Architectural Institute of Korea. 2011 December;27(12):139-46.

3. Kim YR, Kim OJ, Kim DS, Khil BS, Kim SS, Choi SJ. Investigation on the fundamental properties of low heat concrete using high volume mineral admixture. Proceedings of the Korea Institute of Building Construction; 2010 November 12; Daejeon (Korea). Seoul (Korea): Korea Institute of Building Construction;2010. p. 65-8.

4. Han CG, Hwang YS, Lee SH, Kim GD. Influence of admixture on the strength development of concrete at Early
Age. Journal of the Architectural Institute of Korea. 2003 September;19(9):95-102.

5. Sung KT, Hong CW. Strength Development Properties of Concrete with Curing Temperature. Journal of the Industrial Sciences. 1998 August;6(1):313-20.

6. Kim YR, Song YC, Kim HR, Jang SW, Nam SS, Park JH. Investigation on properties of low cement concrete with accelator type of hydration. Proceedings of the Korea institute of building construction; 2012 May 18; Jeonju (Korea). Seoul (Korea): the Korea institute of building construction; 2012. p. 195-6.

7. CMC. Technology of chemical admixtures for concrete. Tokyo (Japan): CMC Publishing Company; 2006. 304 p.

8. Kim YY, Lee JK, Song H, Chu YS, Kwon CW, Park NK. Hydration properties of cement mortars using active admixture. Proceedings of the Fall Symposium of the Korea Concrete Institute; 2007 November 3; Suwon (Korea). Seoul (Korea): Korea Concrete Institute; 2007. p. 785-8.

9. Jo BW, Park MS, Park SK. Strength development and hardening mechanism of alkali activated fly ash mortar. Journal of the Korea Concrete Institute. 2006 August;18(4):449-58.

10. Jeong SW, Lim NG. Study of non sintered cement mortar using nanoslag and alkali activator. Journal of the Korea Institute of Building Construction. 2010 December;10(6):61-6. 